\title{
Converging Divergences in Formal and Informal Work: Longitudinal Evidence from Mexico
}

\author{
Diana Denham, Portland State University, USA \\ Chris Tilly, University of California Los Angeles, USA
}

\begin{abstract}
Analyses of neoliberal labor market restructuring debate whether neoliberalism is homogenizing jobs or polarizing them. Analyses of informal employment debate whether such employment is inferior, and if so, if it is typically a transition or a trap. This paper speaks to both debates, using a three time-point $(2006,2007,2008)$ longitudinal survey of retail workers in the state of Tlaxcala, Mexico, to contrast workers' experiences across the spectrum of formal and informal work. Using the longitudinal data, the paper compares workers' trajectories, exploring how they make choices and navigate transitions between more formal and more informal work. A qualitative portion of the survey permits the comparison of people's aspirations and insight into how those aspirations shift overtime.

Differences within formal and informal retail sectors loom as large as differences between the two sectors. For example, while formal retail workers earned more and in most cases have greater earnings growth than informal ones, much of the earnings advantage disappears when we excluded formal retail supervisors and managers and focus on rank-and-file workers. Class and gender, in addition to market position, structure differential access to better outcomes. Transitions between formal and informal work are rare in this sample, and progress toward aspirations are very limited for most subgroups. The expansion of retail chains appears to be degrading job quality among informal retail workers (through heightened competition), but without leading to better jobs for the typical employee in the chains. In addition, large numbers of job-seekers without viable alternatives are entering informal retail, once more degrading job quality through added competition.
\end{abstract}

\section{KEYWORDS}

Informal work; mobility; neoliberalism; retail.

\section{Introduction and Literature}

The country-level impact of neoliberal restructuring on labor markets is hotly debated. One central debate concerns the extent and pattern of homogenization or polarization in job quality taking place within national workforces (Carré et al., 2012). Whereas some argue that a process of work degradation is homogenizing jobs at a low level (Harrison and Bluestone, 1988: 195; Gonçalves and Madi, 2011: 107, 109), others have pointed to heightened polarization as the main result, and have explored the ways that worker characteristics lead to sorting across divergent outcomes (Kalleberg, 2012). More sophisticated investigations of these questions examine not just 
the evolution of cross-sections of earnings or other measures of job quality, but also the trajectories of individuals over their careers, since poor quality jobs are of greatest concern if people are stuck in jobs of that quality level (Andersson, Holzer, and Lane, 2005).

Though this debate, dominated by voices from the North, has focused empirically on formal employment, the larger concerns motivating it apply equally to informal work, especially given evidence for the expansion of informality, and informalization of nominally formal employment, in both the North (e.g. Bernhardt et al., 2008) and the South (e.g. Tilly et al., 2013). It thus connects to continuing controversies regarding informal employment. Theoretically, perhaps the longeststanding discussion in the literature on informality considers whether informal work is dualist (a holdover of archaic forms of work organization originating outside the modern economy), legalist (entrepreneurship seeking alternative channels due to overly restrictive regulations), or survivalist (the last resort of those with no viable economic alternative) (Avirgan, Bivens, and Gammage, 2005). Empirically, then, there has been much attention to the relative quality of formal and informal jobs and to mobility between one status and the other. This literature has particularly flourished in Latin America, and we review it selectively below.

We speak to these debates with a study of formal and informal retail jobs in Mexico. In particular, we address three questions. First, to what degree is there divergence or convergence between formal and informal retail workers, and within each of these retail subsectors? Second, what are the roles of market position, gender, and class in structuring retail workers' outcomes and trajectories? Finally, how has Mexico's neoliberal economic restructuring, and in particular the remaking of the retail sector itself, affected the quality of jobs and the nature of Mexicans' labor market strategies?

Retail employment presents an ideal setting for exploring these issues, since retail jobs in Latin America straddle formal and informal employment, extending from global chains to self-employed street vendors. Mexico is of particular interest because it represents a classic case of neoliberal restructuring, because formal and informal employment are large and diverse, and because the quality of formal and informal work have been extensively studied, giving us a baseline of empirical literature (de la Garza, 2012a). In this paper, we draw on a three time-point $(2006,2007,2008)$ longitudinal survey of retail workers in the state of Tlaxcala, Mexico. Using longitudinal data, we can compare trajectories, not just point-in-time outcomes, of workers. We track earnings and degree of security and mobility. We also track people's preferences via questions about aspirations. Importantly, longitudinal data enable us to compare people's experiences with their aspirations, and follow how those aspirations themselves shift. We pay particular attention to differences by market position, class, and gender.

Informal work is subject to varied and evolving definitions. We define informal work as work that creates legal goods or services, but does not offer the standard terms and benefits specified for jobs under law - either because the law does not cover these particular jobs, or because the law is not effectively enforced. This definition, which has the advantages of conceptual clarity and broad applicability, follows Castells and Portes (1989), and has since been widely adopted (e.g. Hussmanns, 2004). To implement the definition, we adopt an elaboration proposed by Cobb, King and Rodriguez (2009), who replace the unrealistically rigid ideal-type dichotomy between formal and informal work with a more flexible spectrum of formality. They consider four aspects of formality (consistency of wage reporting, adherence to labor laws, employment steadiness, and legality of working status), noting that various combinations can be observed. Temkin (2008), studying Mexico, similarly defines three levels of informality, having one, two, or all three of the characteristics of working without a formal contract, lacking social security, or working in 
establishments that do not issue official receipts. We apply a similar framework to a range of retail workers across a spectrum of formality.

Informal employment is typically viewed as inferior employment (e.g. Fields, 2004). Most Mexican researchers have reported results corresponding to this view (Levy, 2008; Negrete, 2012). Informal workers themselves seem to agree: Temkin (2009), analyzing an opinion survey of Mexican workers, finds informal employees report feeling less satisfied and in control of their work and lives than formal employees, but that the informal self-employed are the most unhappy of all. However, a growing literature posits that informal work is often superior. De Soto (1989) champions the legalist position, arguing that much informal business activity is simply entrepreneurship driven underground by excessive regulation. Moreover, according to some data, higher income individuals, especially business owners, are more likely to conceal economic activity (Waldinger and Lapp, 1993). But even at the lower end of the labor market, informal employment may offer higher wages, greater schedule flexibility, or other advantages that make it preferable (Maloney, 2004).

Particularly notable in tackling these questions is a set of studies of longitudinal data in Mexico (Bargain and Kwenda, 2011; Maloney, 2003; Gong, van Soest, and Villagomez, 2004), Brazil (Bargain and Kwenda, 2011; Ulyssea and Szerman, 2006), Chile (Joubert, 2011), and Central America (Funkhouser, 1997) that track transitions between formal and informal employment and examine the supply- and demand-side determinants of ending up in one or the other sector. While shedding new light on labor market trajectories, it has generated continuing debate about the relative quality of formal and informal employment. Maloney (1999) and Bosch and Maloney (2007) report that informal workers do better, whereas Bargain and Kwenda (2009-2011) distinguish between salaried work, in which formal workers fare better, and self-employment, in which, at least in Brazil, informal proprietors earn more.

This longitudinal literature also generates estimates of the frequency of transitions between formal and informal employment. For example, Gong et al. (2004) estimate that as many as 20 percent of Mexican men and 10 percent of women who started out in the informal sector had moved to the formal sector as of one year later. These levels of mobility suggest that for many, informality may not be a trap, but just one stop in a longer trajectory. Interestingly, while Gong and co-authors find mobility in and out of informal jobs more rapid than for formal ones, Ulyssea and Szerman conclude that, at least in Brazil, there is an 'informality trap' that sharply reduces exit from informality after the first several months.

Despite these important recent exceptions, most literature on informal employment is crosssectional in nature, remaining silent on the question of mobility over time. Moreover, the longitudinal analyses cited above are strictly quantitative, omitting variables that capture individuals' perspectives, aspirations, or strategies. Our strategy in this research was to conduct in-person interviews in order to learn about these more qualitative aspects of the work experience and specifically to assess workers' degree of goal attainment. Our Mexican sample was small and nonrepresentative, but stratified to include various sectors of retail.

As noted briefly above, Mexico, and its retail sector in particular, are of interest for a number of reasons. Mexico has experienced thorough-going neoliberalization since the 1980s, with concomitant expansion of degraded, precarious, and informal employment (de la Garza, 2012a). Shifts in sectoral mix and increasing employer avoidance of labor regulations have expanded informality from the labor demand side, whereas anemic overall job creation has expanded the supply of desperate workers for whom informal work is the best available option. In 2010, an estimated 61 percent of Mexico's employed worked informally, in the sense of working in nonregistered businesses or in formal businesses but without enjoying basic worker rights (de la Garza, $2012 \mathrm{~b}$ ). Retail is of interest because, as pointed out above, it includes extensive formal and informal 
labor components, with giant, modern retailers such as Walmart dominating the formal portion, while street vendors anchor the informal end (Tilly, 2006). The rapid expansion of both big-box and convenience store chains is very new in Mexico, as in Latin America as a whole. Indeed, the growing global dominance of giant retailers is often identified as a central feature of neoliberal globalization (Lichtenstein, 2009). In the Mexican context, retail is also the largest single employment sector: about one Mexican worker in five works in retail (Tilly and Álvarez, 2006). Among informal workers, more than one in three works in informal retail (de la Garza, 2012). Despite this, the retail workforce as a whole remains understudied. There are notable studies of street vendors (e.g. Cross, 1998; Olivo, 2012), but only a few of workers in formal retailers, most of which focus on Walmart (e.g. Carré and Tilly, 2013; ProDESC, 2009). The workforce turnover rate in formal retail is estimated at 120 percent by the Asociación Nacional de Tiendas de Autoservicio y Departamentales (ANTAD), the Mexican retailers' association, suggesting that longitudinal study is particularly appropriate in order to be able to follow workers who pass through retail employment.

The findings point to complexity rather than simple dichotomies. We find that on average, formal retail workers earn more and in most cases have greater earnings growth than informal ones. However, much of the earnings advantage disappears when we exclude formal retail supervisors and managers and focus on rank-and-file workers. We also find large income disparities among informal retailers, both by format and within formats. Only a minority of workers in any of the categories transitioned out of their initial jobs, and cases of mobility to a different retail sector or out of retail altogether are rare indeed - particularly for workers starting out in informal jobs. As regards goal attainment, workers in our sample had relatively modest aspirations - above all, to open or expand one's own business. Most made some progress toward those aspirations over the two-year study period, but typically the progress was extremely limited, and quite a few workers slipped backwards. Confronted with these harsh realities, many lowered their expectations over time.

In short, we encounter both divergences within retail sub-sectors, but convergence between non-managerial formal retail workers and informal retail workers - a combination of polarization and homogenization. ${ }^{1}$ Class and gender, in addition to market position, structure differential access to better outcomes. The expansion of retail chains appears to be degrading job quality among informal retail workers (through heightened competition), but without leading to better jobs for the typical employee in the chains. In addition, large numbers of job-seekers without viable alternatives - arguably a product of Mexican neoliberal policies undermining small-scale agriculture and import substitution manufacturing-are entering informal retail, once more degrading job quality through added competition.

\section{Methods and Data}

We gathered a convenience sample of 91 workers in food retailing in the state of Tlaxcala, Mexico in spring 2006. Tlaxcala is Mexico's smallest state, located about 100 kilometers east of Mexico City in central Mexico. We sampled workers by walking and driving through the commercial areas of the major cities of Tlaxcala, entering retail establishments, and inviting workers to participate in the study. Workers were concentrated in the capital city of Tlaxcala and its twin city, the commercial center of Santa Ana Chiautempan. However, we also included workers in several smaller cities. Although we report numbers and percentages, it is important to keep in mind that due to the convenience nature of the sample, the statistics are only descriptive of the sample itself, and cannot be used for inference about a larger population.

We intentionally sampled from six sub-sectors covering every channel of food retail in Mexico. Table 1 details the sample. From most formal to least formal, the sub-sectors are chain stores, 
supplier services, mom and pops and public market stands (both with about the same degree of formality), tianguis (weekly street market) stands, and independent street vendors. This order is based on our assessment of their degree of compliance with legal regulations, and in particular accurate reporting to government authorities.

The initial (2006) interview gathered information on work history, the retail job, earnings from that and other jobs, household structure, household income sources, and aspirations for one year and five years in the future. In the two subsequent waves, we re-asked all of these questions and asked about progress toward aspirations stated earlier. In these later interviews, we asked about the current job, regardless of whether it was in retail. However, as we shall see, very few respondents left the retail industry.

Based on these interviews, we operationalize class as education (the lines between incomplete secondary education, complete secondary education, and higher education are particularly critical) and social capital (contacts, access to assistance from family, and so on). We operationalize market position via a set of empirically observed competitive advantages, especially what we call locational advantage, meaning location that is central, easily accessible, and/or part of a concentrated retail agglomeration.

Table 1: The Sample and Its Sub-Sectors

\begin{tabular}{|c|c|c|c|c|}
\hline Sub-sector & Description & $\begin{array}{l}\text { Degree of } \\
\text { formality }\end{array}$ & $\begin{array}{l}\text { \# in } 2006 \\
\text { sample }\end{array}$ & $\begin{array}{c}\text { \# with } \\
\text { follow-up } \\
\text { interview(s) }\end{array}$ \\
\hline $\begin{array}{l}\text { Chain } \\
\text { stores }\end{array}$ & National and regional chains of multiple stores & $\begin{array}{l}\text { Highly } \\
\text { formal }\end{array}$ & $\begin{array}{l}38 \text { (including } \\
21 \text { supervisors } \\
\text { \& managers) }\end{array}$ & 24 \\
\hline $\begin{array}{l}\text { Supplier } \\
\text { services }\end{array}$ & $\begin{array}{l}\text { Includes commission wholesale salespeople } \\
\text { and promotores marketing products to } \\
\text { consumers in the store }\end{array}$ & $\begin{array}{l}\text { Relatively } \\
\text { formal }\end{array}$ & 8 & 5 \\
\hline $\begin{array}{l}\text { Mom and } \\
\text { pop stores } \\
\text { (abarrotes) }\end{array}$ & $\begin{array}{l}\text { Small, individually owned stores in fixed, fully } \\
\text { enclosed locations }\end{array}$ & $\begin{array}{l}\text { Moderately } \\
\text { formal }\end{array}$ & 18 & 11 \\
\hline $\begin{array}{l}\text { Public } \\
\text { market }\end{array}$ & $\begin{array}{l}\text { Stands in open areas of enclosed public } \\
\text { markets }\end{array}$ & $\begin{array}{l}\text { Moderately } \\
\text { formal }\end{array}$ & 7 & 6 \\
\hline $\begin{array}{l}\text { Tianguis } \\
\text { (weekly } \\
\text { markets) }\end{array}$ & $\begin{array}{l}\text { Stands that set up in weekly markets that locate } \\
\text { in a different place each day of the week }\end{array}$ & $\begin{array}{l}\text { Relatively } \\
\text { informal }\end{array}$ & 8 & 8 \\
\hline $\begin{array}{l}\text { Independent } \\
\text { street } \\
\text { vendors }\end{array}$ & $\begin{array}{l}\text { Selling out of house or on the street, not in fixed } \\
\text { location markets or tianguis. Includes some } \\
\text { purely self-employed and some selling branded } \\
\text { goods such as popsicles. }\end{array}$ & $\begin{array}{l}\text { Highly } \\
\text { informal }\end{array}$ & 12 & 10 \\
\hline TOTAL & & & 91 & 65 \\
\hline
\end{tabular}

In the initial interview, we gathered varied contact information in order to be able to recontact workers in future years. We were able to re-contact 65 (71 percent) of the original 91 
respondents in spring 2007, spring 2008, or both. We reached all but 6 of those 65 in 2008 . Interviews were recorded and transcribed.

To obtain quantitative totals across all retail sectors, we weighted the means or proportions from each sector by weights based on employment estimates from the 2009 Economic Census for stores, suppliers, and public market stands, and based on the 2012 Encuesta Nacional de Ocupación y Empleo (ENOE) for tianguis mobile market stands and ambulant street vendors (we thank Enrique de la Garza Toledo for ENOE tabulations; contact authors for details of weight estimation).

Because the narrative refers to chains by name, Appendix Table A offers capsule descriptions of the chains in the sample.

Beginning in 2007 and continuing into 2008, the US economy sank slowly into recession (the financial crisis exploded later in 2008, after these surveys), and the Mexican economy correspondingly slowed down as well. Indicators of labor market distress show that Tlaxcala's labor force was hit moderately hard by this deepening downturn (see Appendix Table B).

\section{Findings}

We present findings in three areas: earnings and earnings growth, security and mobility (starting with a summary of workers' aspirations), and the degree to which aspirations are realized. These variables have the advantages of measurability, broad comparability across jobs and over time, and relative objectivity.

\section{Earnings levels and changes}

In examining earnings, we seek to discern the degree of convergence or divergence between formal and informal retail work, and how recent economic restructuring has affected earnings. Retail work, in general, pays much better than minimum wage. However, at around $\$ 6.50$ per day (in purchasing power U.S. dollars), workers who depend exclusively on this daily minimum wage live in extreme poverty. In this study, 10 percent of workers earned at or below the minimum wage during at least one year. Mexican pesos have been converted to U.S. dollars using the Purchasing Power Parities provided by the OECD.

As shown in Table 2, retail workers and worker-owners in our sample earned an average of 596 dollars per month (\$25 daily) from 2006 to 2008. In the aggregate, more workers in more formal businesses - chain stores and supplier services - earned substantially more than those in more informal formats. Chain store workers averaged $\$ 34$ a day and $\$ 823$ a month, with supplier service workers earning even more. In contrast, workers in the less formal formats were clustered around \$15-20/day and \$350-500/month. Each of these averages conceals a wide set of divergences: the ratio of lowest to highest monthly pay rates ranged from about 3:1 for supplier services to nearly 9:1 for the tianguis market.

Once we separate chain supervisors and managers from everyday employees, new divergences and convergences emerge: we find divergence within chain employees, and convergence between lowend chain employees and informal retail workers. Whereas managerial employees have earnings similar to those in supplier services (the highest earner, the owner-manager of an Oxxo convenience store, earned \$2000 a month), non-managerial chain store workers have lower earnings than workers in any of the less formal formats (with the lowest earner, stocking electronics at a Gigante superstore, earning only $\$ 139 /$ month). The expansion of corporate retail has actually created worse jobs for workers at the bottom of the pyramid. 
Table 2: Annual Monthly \& Daily Income (in USD) by Sub-Sector (averages across the three waves)

\begin{tabular}{|l|r|r|}
\cline { 2 - 3 } \multicolumn{1}{l|}{} & Monthly & \multicolumn{1}{c|}{ Daily } \\
\hline Chains & $\$ 823$ & $\$ 34.31$ \\
\hline - Chains-Supervisorial & 1,186 & 49.41 \\
\hline - Chains-Non-supervisorial & 383 & 15.95 \\
\hline Supplier Services & 1,261 & 52.54 \\
\hline Mom and Pop stores & 407 & 16.94 \\
\hline Public Market & 510 & 21.26 \\
\hline Tianguis & 391 & 19.53 \\
\hline Independent street vendors & 410 & 17.06 \\
\hline TOTAL AVERAGE & $\mathbf{5 6 5}$ & $\mathbf{2 3 . 9 4}$ \\
\hline
\end{tabular}

Note: All numbers in Purchasing Power Parity US Dollars (USD)

Supplier services show stratification of earnings by job category as well. The wholesale salespeople (all men) earned considerably more than the store-based promotoras (all women) promoting products to customers. Serena [all names are pseudonyms], who promoted dairy products, and described her responsibilities as 'waiting on customers, receiving product and checking expiration dates' earned the least of the supplier services workers, with an average monthly salary of $\$ 433$ in 2006.

The earnings gaps between various worker categories are shaped particularly by market position. The higher average level of daily earnings of supervisors, managers, and sales personnel in more formal retail channels is tied to both market position (relative to informal groups) and class (relative to frontline workers). Unsurprisingly, formal businesses (chains and supplier services) with prime locations, larger formats (offering convenient, quick one-stop shopping), and investments in equipment and systems, were able to sell larger volumes and provide higher pay to their upper level workers. Supervisory and management positions, middle class jobs which typically require at least some college, pay more than line worker positions in the chain stores.

Different market positions, and in particular locational advantages, also distinguish the various less formal channels. The public market - well-known, centrally located, offering a wide variety of merchandise and open every day (thus offering convenience relative to other informal formats) provided the highest incomes after retail chains, and within the public market, owners of larger or multiple stalls earned more than those with smaller, single stalls. Mom and pop stores enjoy the advantages of week-long operation in a fixed site, but are less centrally located, offer limited goods, and typically just serve customers from a single neighborhood.

In contrast with the public market and corner stores, tianguis weekly street markets circulate to different locations each day of the week, limiting their ability to make capital investments or build up a faithful clientele. Vendors in our sample typically specialized in one type of product (for example fruits, vegetables, cheese or seeds) and had a very small assortment. Because of the licensing system and the time needed to travel from one market to another, vendors at the rotating street markets typically have only four days to sell, whereas other businesses are open at least six days a week (and are also open longer hours). Importantly, unlike the indoor public market, with a fixed number of stalls, tianguis are located outdoors under temporary awnings, and the number of vendors 
can easily be increased. Thus, tianguis stands have more limited access to consumer demand and are more vulnerable to competing supply.

Independent vendors have the smallest scale, the least capital, and are the least protected from entry by other competing sellers. Their situations varied, with most preparing their own merchandise (sweets or potato chips, for example) and selling them on the street or in a corner of the market without a formal stand. One self-employed vendor sold fruit and vegetables from a stand in front of her house, another circulated a sweets cart around the public market, and another sold popsicles supplied by the BonIce brand. These businesses were typically constrained by their size; control of only a very small space and lack of storage capacity limited the quantity and assortment of merchandise to what they could expect to sell in a given day. Even so, their earnings were comparable to (and slightly above) their mom and pop counterparts.

Though earnings of formal retail workers benefit from their business's competitive advantages of central locations and economies of scale, informal workers have access to other strategies to increase total household income. Perhaps most importantly, less formal family businesses typically deploy unpaid family workers. Most owner-workers in the sample hired family members or otherwise depended on their free labor. In calculating monthly and weekly earnings in family businesses, we divided by the number of adults working, to avoid inflating earnings estimates. Given this adjustment, adult unpaid family workers add nothing to the per-adult earnings we report, but in terms of household survival strategy they add to total family income without any added out-ofpocket cost.

Another strategy to increase total income is holding multiple jobs. Particularly common is the case of people who hold a formal job, but add a flexible, informal job to supplement their income. For instance, Carlos worked as a university professor, but his flexible work schedule also permitted him to operate first one, then multiple corner stores.

Real earnings among Tlaxcala retail workers rose by 13 percent between 2006 and 2007, but only by 2\% between 2007 and 2008 as the slowdown in the US economy rippled through Mexico. The changes in earnings are summarized in Table 3. The net growth was concentrated in the more formal sectors: chains, vendor services and public markets. In chains, non-managerial workers gained more than managers in the upturn, but lost more in the downturn. Surprisingly, public markets were the only sector where earnings continued to grow even during the economic downturn that began to affect retail in 2007. This sector's 68 percent increase in income over three years was the highest of any sector, followed by supplier services at 59 percent and chains at 20 percent. The rest of the less formal sectors all saw negative growth rates. Losses in the tianguis rotating street market sector were most dramatic: 100 percent of vendors saw an income decline.

Worker-owners blamed competition that cut into already low profits, and their analysis points out to the continuing effects of neoliberal restructuring. The biggest culprits they pointed to are the chains, particularly the gigantic autoservicios offering variety and convenience. Melisa, a public market worker, reported that with the opening of Aurrera in 2003, her sales dropped immediately by as much as $\$ 6.50$ per day - the equivalent of her daily income in 2007.

Some street market vendors reported an increase in hours in order to try to recoup this loss of income. Despite increasing their hours, the rising price of inputs and low rates of consumption prevented a corresponding rise of income. David, who sold fruit and DVDs at the street markets, went from four days a week in 2006 to seven days in 2008, but his income dropped from $\$ 612$ to $\$ 348$ over the same years - a total decline of $43 \%$. This pattern was noted by people in all of the less formal retail sectors. Employees in small and informal businesses reported working increased hours for less pay, and worker-owners reported earning less despite long hours. 
Table 3: Percent Change in Earnings by Sector

\begin{tabular}{|l|c|c|c|}
\cline { 2 - 4 } \multicolumn{1}{c|}{} & \begin{tabular}{r} 
\% change \\
\multicolumn{1}{c|}{$2006-2007$}
\end{tabular} & $\begin{array}{c}\% \text { change } \\
\mathbf{2 0 0 7 - 2 0 0 8}\end{array}$ & $\begin{array}{c}\text { \% change } \\
\mathbf{2 0 0 6 - 2 0 0 8}\end{array}$ \\
\hline Chains & $21 \%$ & $-1 \%$ & $20 \%$ \\
\hline - Chains-Supervisorial & $13 \%$ & $-1 \%$ & $12 \%$ \\
\hline - Chains-Non-supervisorial & $34 \%$ & $-9 \%$ & $22 \%$ \\
\hline Supplier Services & $35 \%$ & $18 \%$ & $59 \%$ \\
\hline Mom and Pop stores & $-1 \%$ & $-13 \%$ & $-15 \%$ \\
\hline Public Market & $49 \%$ & $12 \%$ & $68 \%$ \\
\hline Tianguis & $17 \%$ & $-47 \%$ & $-37 \%$ \\
\hline Independent street vendors & $-7 \%$ & $1 \%$ & $-6 \%$ \\
\hline ALL Retail Workers & $13 \%$ & $2 \%$ & $15 \%$ \\
\hline
\end{tabular}

Note: Includes only workers who stayed in the same retail sector.

As documented below, this is the overwhelming majority of workers.

Yet large chains are not the only source of competition. As the economy worsens and the supply of job-seekers expands, informal retail is one of the most common industries that workers turn to. Very small-scale informal workers who have no overhead costs sometimes create another important source of competition that small-business owners face. Public market vendor Melisa attributed her dramatic drop in income not only to Aurrera, but also to the emergence of more informal vendors. She described a new local government policy to expand the vending zone around the public market in order to offer more economic opportunities for the unemployed. As she pointed outside to a whole new section of the market where people sold the same goods as her and the other workers-owners around her, she said: 'I think there are too many of us. So much competition now... Every year we sell less and less.'

In brief, two outcomes of neoliberal restructuring - expanded corporate competition and a flood of unemployed and underemployed workers - undermined retail workers' earnings, especially in informal retail. Based on our evidence, we cannot definitively answer why public market earnings bucked this trend. However, a possible explanation is that in economic hard times, former patrons of chain retailers 'traded down' to the cheaper but still relatively convenient public markets - much as consumers in the United States switched from Walmart to the even lower-priced dollar stores during the recession.

\section{Mobility and security}

A starting point for evaluating mobility and security is to consider what the workers themselves hoped to achieve. Worker aspirations, for each sub-sector and for the total, are shown in Table 4. Every worker expressed at least one aspiration, and the great majority expressed more than one. We classify the goals as advancing within informal employment, advancing within formal employment, more general financial goals, and the 'exit' option of migration abroad to seek work.

By far the most frequent goal expressed by the food retail workers interviewed was to open their own business. Over half of all workers hoped to open a business within the next one to five years. The most common kind of business that people imagined opening was a small grocery store in 
front of their homes (typically informal). In addition, most of those who already owned a business hoped to expand or improve their business.

Workers' reasons for wishing to open a business reflect the disadvantages of corporate employment in Mexico's neoliberal regime - and thus the continuing appeal of informality. First, many, even those formally employed at large chains, who might expect to receive a pension, saw opening their own business as a sort of social security, recognizing the precariousness and insecurity of corporate employment over the longer run.

Second, many expressed a preference for self-employment due to autonomy, control over one's social time, and social status. Francisco, who rated his sales job in supplier services a 10 on the scale of 1 to 10 , and considered it very well-paying, still said he planned on quitting as soon as he had enough money to invest in a small grocery store: 'Working for someone else is good, but having your own business is better.'

On the formal side, getting promoted to a higher level position was an objective of most retail workers in chains and vendor services. Two-thirds of chain store employees hoped to move up. However, this breaks down to almost every supervisor and manager, and less than half of the line employees. It is interesting to note that moving up the career ladder was an aspiration most often named in conjunction with, rather than exclusive of, opening one's own business. Three-quarters of those who aimed to move up also hoped to open their own business.

Table 4: Distribution of Aspirations by Sub-Sector (Percentage expressing each aspiration)

\begin{tabular}{|c|c|c|c|c|c|c|c|c|c|}
\hline & \multicolumn{2}{|c|}{$\begin{array}{c}\text { Informal } \\
\text { Advancement }\end{array}$} & \multicolumn{3}{|c|}{ Formal Advancement } & \multicolumn{3}{|c|}{ Financial Advancement } & \multirow{2}{*}{$\begin{array}{c}\text { Exit } \\
\text { Migrate }\end{array}$} \\
\hline & $\begin{array}{c}\text { Open } \\
\text { Business }\end{array}$ & $\begin{array}{l}\text { Improve } \\
\text { Business }\end{array}$ & $\begin{array}{c}\text { Find } \\
\text { Another } \\
\text { Job }\end{array}$ & Move up & Study & $\begin{array}{l}\text { Invest in } \\
\text { House, } \\
\text { Car, } \\
\text { Furniture }\end{array}$ & $\begin{array}{c}\text { Save } \\
\text { Money }\end{array}$ & $\begin{array}{l}\text { Spend } \\
\text { on } \\
\text { Family } \\
\end{array}$ & \\
\hline Chains & $63 \%$ & $4 \%$ & $29 \%$ & $67 \%$ & $21 \%$ & $13 \%$ & $8 \%$ & $8 \%$ & $42 \%$ \\
\hline $\begin{array}{l}\text { Chains: } \\
\text { Supervisorial }\end{array}$ & $75 \%$ & $0 \%$ & $25 \%$ & $92 \%$ & $8 \%$ & $8 \%$ & $0 \%$ & $8 \%$ & $58 \%$ \\
\hline $\begin{array}{l}\text { Chains: Non- } \\
\text { supervisorial }\end{array}$ & $50 \%$ & $8 \%$ & $33 \%$ & $42 \%$ & $33 \%$ & $17 \%$ & $17 \%$ & $8 \%$ & $33 \%$ \\
\hline $\begin{array}{l}\text { Supplier } \\
\text { Service }\end{array}$ & $100 \%$ & $0 \%$ & $40 \%$ & $60 \%$ & $0 \%$ & $0 \%$ & $0 \%$ & $20 \%$ & $20 \%$ \\
\hline Mom \& Pops & $36 \%$ & $36 \%$ & $45 \%$ & $0 \%$ & $18 \%$ & $18 \%$ & $9 \%$ & $18 \%$ & $55 \%$ \\
\hline Public Market & $33 \%$ & $67 \%$ & $33 \%$ & $0 \%$ & $17 \%$ & $50 \%$ & $0 \%$ & $0 \%$ & $33 \%$ \\
\hline Tianguis & $38 \%$ & $63 \%$ & $25 \%$ & $0 \%$ & $13 \%$ & $63 \%$ & $13 \%$ & $0 \%$ & $63 \%$ \\
\hline $\begin{array}{l}\text { Independent } \\
\text { Street Vendor }\end{array}$ & $64 \%$ & $55 \%$ & $18 \%$ & $0 \%$ & $18 \%$ & $18 \%$ & $0 \%$ & $0 \%$ & $9 \%$ \\
\hline TOTAL & $55 \%$ & $31 \%$ & $31 \%$ & $29 \%$ & $17 \%$ & $23 \%$ & $6 \%$ & $8 \%$ & $40 \%$ \\
\hline
\end{tabular}

Studying-including high school, college, English or computer classes, or further job training - was one of the least likely aspirations to be named (in part because of the wide range of ages represented in the sample). About one in six retail workers expressed a desire to study more. 
About one-fifth of workers simply expressed goals of purchasing durable goods such as a house or car, saving money, or undertaking the expenses to start a family or help family members advance.

Finally, forty percent of workers had thought about exiting the Mexican labor market altogether and migrating to the United States - joining a stream that has expanded massively in the neoliberal era. Interestingly, high percentages of workers not only in informal sectors, but also among college-educated retail managers, contemplated this possibility.

We find that workers' ability to translate these varied aspirations into reality was limited by inequalities within the expanding corporate retail sector, as well as heightened competition driven by the expansion of large chains simultaneous with the flood of people without other options into informal retail work.

Workers did strive to better their positions. Most importantly, many workers attempted to improve or at least preserve their earnings by changing jobs, including some changes from formal to informal employment and vice versa. However, as Table 5 shows, the majority -57 percent - of retail workers remained in their original jobs over the two year span of this study. Most who changed jobs did so within the same company. We saw very few cases of workers departing retail altogether. A few left the work force outright: all were women who did so because of family obligations, and all were from the mom and pop sector.

Table 5: Transition Matrix of Retail Workers, 2006-08

\begin{tabular}{|c|c|c|c|c|c|c|}
\hline $\begin{array}{l}\text { Destination } \\
\text { Origin }\end{array}$ & $\begin{array}{l}\text { Remain } \\
\text { in same } \\
\text { retail job }\end{array}$ & $\begin{array}{c}\text { Moved } \\
\text { up } \\
\text { in same } \\
\text { company }\end{array}$ & $\begin{array}{c}\text { Same } \\
\text { sector but } \\
\text { different } \\
\text { employer }\end{array}$ & $\begin{array}{l}\text { Moved to } \\
\text { a different } \\
\text { retail Sector }\end{array}$ & $\begin{array}{l}\text { Moved } \\
\text { outside of } \\
\text { retail }\end{array}$ & $\begin{array}{c}\text { Non- } \\
\text { employment }\end{array}$ \\
\hline Chains & $38 \%$ & $33 \%$ & $17 \%$ & $8 \%$ & $4 \%$ & $0 \%$ \\
\hline $\begin{array}{l}\text { Chains } \\
\text { - Supervisorial }\end{array}$ & $50 \%$ & $25 \%$ & $25 \%$ & $0 \%$ & $0 \%$ & $0 \%$ \\
\hline $\begin{array}{l}\text { Chains } \\
\text {-Non-supervisorial }\end{array}$ & $25 \%$ & $42 \%$ & $8 \%$ & $17 \%$ & $8 \%$ & $0 \%$ \\
\hline Supplier Services & $60 \%$ & $20 \%$ & $20 \%$ & $0 \%$ & $0 \%$ & $0 \%$ \\
\hline Mom and Pop stores & $45 \%$ & $0 \%$ & $9 \%$ & $0 \%$ & $27 \%$ & $18 \%$ \\
\hline Public Market & $83 \%$ & $17 \%$ & $0 \%$ & $0 \%$ & $0 \%$ & $0 \%$ \\
\hline Tianguis & $100 \%$ & $0 \%$ & $0 \%$ & $0 \%$ & $0 \%$ & $0 \%$ \\
\hline $\begin{array}{l}\text { Independent street } \\
\text { vendors }\end{array}$ & $64 \%$ & $9 \%$ & $9 \%$ & $18 \%$ & $0 \%$ & $0 \%$ \\
\hline ALL Retail Workers & $57 \%$ & $17 \%$ & $9 \%$ & $8 \%$ & $6 \%$ & $3 \%$ \\
\hline
\end{tabular}

In general, less formal retail channels had more stable employees. Four out of five public market worker-owners, and all of the tianguis workers, were in the same job two years later. Given the distinct fortunes of public market and tianguis workers, we surmise that the former case represents security in a decent job, whereas the latter represents a lack of options - adding to the evidence for divergence within informal retail. 
At the other extreme, only one-quarter of non-supervisorial chain store employees occupied the same job two years later. Among less formal formats, mom and pop stores had exceptionally high mobility, but this was entirely due to the women who left to care for children. Many mom and pops are supplemental income projects for middle class families, making this kind of exit economically feasible.

Table 6: Job Transitions and Income Changes

\begin{tabular}{|l|c|c|}
\cline { 2 - 3 } \multicolumn{1}{c|}{} & $\begin{array}{c}\text { \% with Any Job } \\
\text { Change }\end{array}$ & $\begin{array}{c}\text { \% with Change that Resulted in Higher } \\
\text { Income }\end{array}$ \\
\hline Chain & $63 \%$ & $80 \%$ \\
\hline Chains: Supervisorial & $50 \%$ & $83 \%$ \\
\hline Chains: Non-supervisorial & $75 \%$ & $78 \%$ \\
\hline Supplier Services & $40 \%$ & $50 \%^{*}$ \\
\hline Mom and Pop stores & $36 \%$ & $50 \%^{* *}$ \\
\hline Public Market & $17 \%$ & $100 \%{ }^{*}$ \\
\hline Tianguis & $0 \%$ & -- \\
\hline Independent street vendors & $36 \%$ & $50 \%$ \\
\hline ALL Retail Workers & $40 \%$ & $69 \%$ \\
\hline
\end{tabular}

* These estimates are based on one to two observations, so are particularly unreliable.

** This estimate only includes people who continued doing paid work, and does not include several women who left the paid workforce.

Table 6 shows the percentage changing jobs within each sector, and the percentage of changers who gained earnings via the change. Most job changes resulted in earnings increases, especially for those starting out in chain stores and the public market. Importantly, chain store line workers' job changes were overwhelmingly tied to increased income, suggesting that their high turnover is linked to upward mobility rather than short-run insecurity. However, they were less likely to increase their incomes than chain store managers or public market workers who changed jobs, and glancing back at Table 3 reminds us that despite little job movement, public market workers enjoyed far larger increases in income than chain store workers or managers.

Transitions between formal and informal modes of retail were relatively rare. Among the less formal retail formats, from mom and pops to independent street vendors, only two people, 6 percent of the total, moved into formal jobs - and both outside retail. In the reverse direction, a slightly higher 10 percent of chain and supplier service employees (three people) relocated to less formal jobs. These frequencies are considerably lower than those estimated by Gong et al. (2004). Thus workers' relatively advantageous or disadvantageous positions tend to persist over time; in particular, dreams of successful entrepreneurship are rarely fulfilled.

Though movements between formal and informal jobs were unusual, workers pursued five other main strategies in changing jobs. These include two primarily formal job strategies, climbing the corporate ladder and job-hopping; two informal job strategies, starting a business and moving from retail into wholesale; and a final option of exiting the Mexican labor market via migration. In some cases workers combined more than one strategy. Whereas market position helped explain pay 
differences across retail categories, workers' degree of success in pursuing a particular strategy within a particular category was especially shaped by gender and class.

\section{i) Climbing the corporate ladder}

Many workers, especially women, run into limits to moving up within a company. While we found occasional examples of climbing the corporate ladder, most workers felt stuck. Diego, a floor worker at a Gigante supercenter, confronted corporate stratification with a class overlay and found meaningful upward mobility unattainable:

'I'm all alone in my department... I've been here nearly two years and I haven't gotten a raise. For my level of responsibility it's not worth it. When there is a possibility of moving up, they might give you the job, but they won't give you the corresponding salary.'

Similarly, Eleanora promoted Nestlé products for thirteen years without moving up. Though she wished to be supervisor, she knew she would never be offered the job because it required a university degree, one of our markers of class.

\section{ii) Job-hopping}

Eleanora ended up job-hopping to another employer, along with more than one-fifth of the sample. Job-hopping is the most common earnings improvement strategy, but has its limits. Maura, working at a mom and pop, when asked about opportunities to find a better job, cited the barriers posed by social capital, the other class marker. She responded, 'Right now there are very few [opportunities]. If you don't know someone who works at the business, they won't give you a job. Jobs are given more on the basis of contacts than skills.'

\section{iii) Starting a business}

As noted above, starting a business is the most common aspiration. Some retail workers turned this aspiration into a reality during the two-year period. But for most, it did not prove a quick road to riches. After years of employment with little advancement, Daniel started selling popsicles for BonIce, but was once more disappointed. He was among fifty vendors who had left the franchise in 2007 . He began selling belts and bags, spreading his wares out on the sidewalk, earning an average of 135 dollars weekly for sixty-hour weeks - the same hourly income as before. Though he was struggling, he considered his new job an improvement over BonIce. 'Compared to last year, I'm doing better. Last year I just sold juice, I worked for a company. But now I have my own business and that's a good thing. I've come up.'

Increased competition, including from expanding retail chains, limits new startups' possibilities. Maura, the mom-and-pop employee who was discouraged about the prospects for finding a better job, was also pessimistic about her dream of starting a new family business: 'If you look around, there is a business every five steps. Today, it's harder for a business to get off the ground fast.'

\section{iv) Moving from retail into wholesale}

Some of those struggling to make a living in family businesses, particularly entrepreneurial young men, saw income potential in improving their market position by moving further back on the supply chain. David, who had worked at a fruit stand in the tianguis markets since he was 11, did successfully move into wholesale. He was 18 at the time of the first interview, and reported complementing the family fruit business with his own pirated DVD and CD stand. In 2006, he had 
just quit selling CDs and DVDs after running the stand for seven years due to repeated police confiscations of merchandise.

Despite closing the stand, David and his brother used their knowledge of the industry to open a wholesale business, copying and distributing DVDs to other tianguistas. He estimated selling 20 boxes of CDs and 20 boxes of DVDs, with total sales of around $\$ 6000$ per month, and profits of around $\$ 275$. Faced with increasing competition, his income - and with it his job satisfaction eroded over the years despite his best efforts: 'You live from day to day; there's always going to be something that goes wrong.'

\section{v) Migration}

Nearly 40 percent of all people interviewed had considered migrating to the U.S. at some point. David, just mentioned above, pursued this avenue. He migrated to the United States in 2006, but was deported after just a short time in the country. By 2008, he was trying to once more save enough money to pay for the border crossing later that year. Others said that they might have considered migration, but were concerned about the violence along the border, the threat of U.S. border patrol and immigration officers, and exploitation on the job. One tianguis worker remarked, 'An immigrant suffers to get across the border, and the truth is they look on us as strange insects. We're not valued in the U.S...'

\section{vi) Multiple strategies}

Examples of combining multiple strategies illustrate that inflexible scheduling in formal retail can impede mobility, and that mobility is gendered. Noë's story illustrates the first. Noë, an area lead worker at a Waldo's convenience store, studied public accounting, but found the schedule challenging. 'I study. Monday I'm here nights and leave Tuesday morning to run to school. On Tuesdays, I'm often on the afternoon shift, so from school I come back here and I haven't slept in a day.' The scheduling issues blocked his ability to advance, but he continued to take steps towards his goal to open an accounting firm by taking a related internship and adding a box-making job despite pressure from his family to quit school.

Many mobility accounts suggest mobility's gendered nature. Esmeralda, who sold products for the large snack company Sabritas in an Aurrera supercenter, saw her opportunities as limited both by education and gender.

'Any company, any vendor services company...if there is a man, they make him supervisor... Here, a boy who came in out of nowhere, they gave him a position just because he had gone to college. Because he's a man and he has a certain educational level. I've seen it. There was a woman who worked with us who also had studied... and it was obvious that she was the one who should move up, but they did something, they hired a boy who had his B.A. and they left her in the lower position. She quit.'

Trainings, similarly, didn't promote mobility, in her view. 'My first course was sales. The other courses are about self-esteem, physical and moral development, and then they just repeat. They do the same trainings, but with different names.'

In addition, it was only women who left jobs to care for children. Even when care duties were compatible with a job, they could foreclose further education.

\section{Meeting aspirations, or abandoning them?}

To what extent did people make progress in achieving their aspirations over time? Table 7 shows that overall, there was only progress toward meeting one-quarter of total aspirations, and less 
than half of respondents made progress toward any aspiration. Here high-end informal workers converge with their formal counterparts, diverging from the groups of informal workers who occupy weaker market positions. Chain store and supplier service workers, mom-and-pop stores, and public market vendors hit the mark 50-60 percent of the time. On the other hand, tianguis vendors and independent street vendors languished; one in six or fewer progressed.

Some respondents fully met their aspirations, but such success was exceptional. One particularly successful case, which amply illustrates class advantages, was Leonel, who started out promoting credit cards based at large retailers. Like others in supplier services, he hoped to open his own business. Unlike others, he was able to do so within the two-year study period. He doubled his credit card promotion income between 2006 and 2007. His high salary, family capital, and entrepreneurial attitude made him able to achieve most of his rather ambitious goals: between 2006 and 2008, he finished his university degree, switched to a more lucrative job in the same field, and opened a hotel and a corner store in houses owned by his family.

But overall, very few people made any progress towards opening a business over two years only three of 34 people made progress. More typical than Leonel is the case of Claudia. Claudia, a popsicle vendor, hoped to guarantee her family's livelihood by combining several sources of income, rather than just one. She strove to continue studying medicine while selling popsicles, and hoped to open her own taco restaurant. During the research period, she continued studying, but, given the ease of entry by competing vendors, failed to save money towards other future enterprises.

Table 7: Aspiration Achievement by Sub-sector

\begin{tabular}{|l|c|c|c|c|c|c|c|c|c|}
\cline { 2 - 8 } \multicolumn{1}{c|}{} & Chains & $\begin{array}{c}\text { Chains: } \\
\text { Supervisorial }\end{array}$ & $\begin{array}{c}\text { Chains: Non- } \\
\text { Supervisorial }\end{array}$ & $\begin{array}{c}\text { Supplier } \\
\text { Services }\end{array}$ & $\begin{array}{c}\text { Mom } \\
\text { and } \\
\text { Pops }\end{array}$ & $\begin{array}{c}\text { Indep. } \\
\text { Public } \\
\text { Market }\end{array}$ & Tianguis & Vendors & Total \\
\hline $\begin{array}{l}\% \text { of people } \\
\text { with some } \\
\text { progress } \\
\text { toward any } \\
\text { aspiration }\end{array}$ & $54 \%$ & $50 \%$ & $58 \%$ & $60 \%$ & $55 \%$ & $50 \%$ & $13 \%$ & $18 \%$ & $\mathbf{4 2 \%}$ \\
\hline $\begin{array}{l}\% \text { of total } \\
\text { aspirations } \\
\text { on which } \\
\text { there was } \\
\text { progress }\end{array}$ & $33 \%$ & $32 \%$ & $33 \%$ & $40 \%$ & $35 \%$ & $17 \%$ & $6 \%$ & $11 \%$ & $\mathbf{2 5 \%}$ \\
\hline
\end{tabular}

People who wished to invest in businesses they already owned-concentrated in the less formal sectors - were more likely to make progress over two years. Almost half of the 41 percent of the sample with this goal were successful.

Employees in larger businesses (chains and supplier services), two-thirds of whom hoped to move up, were still more successful, as reflected in Table 6. More than half of them did move to a better job during the course of this study. For example, Luís, who started out managing a small Super D convenience store, moved up to assistant manager of a store that was twice as large in one year, and then to managing the store a year later. But Carmina, who had already spent four years as assistant manager at a Farmacia Guadalajara drugstore at the time we first interviewed her, still had not landed a desired store manager job by two years later-perhaps due to gender-based discrimination.

Indeed, even over a two-year period, many respondents deferred or even abandoned cherished dreams. Micaela, an owner of a mom and pop during 2006 interviews, is representative. Micaela had 
gotten loans from family members to open a small grocery store. In 2006, she hoped to open a second store and make her business a chain, but a few weeks before the interview in 2007, she closed the store. Part of the reason was a shift in priorities: 'because I had my baby and I don't have anyone I can leave him with, so I have to take care of him.' Her husband's stable, relatively wellpaying salary as a graphic designer in the textile industry also helped make her decision not to work outside the home possible. But she also highlighted low sales. When Micaela started earning less than 13 dollars per day, she shut down. In 2007, she wished to put her baby in a daycare, take practical courses in computers, and make crafts to sell, but as of her last interview in 2008, she had been unable to do any of these things.

Some retail workers were so discouraged that, in later years in the sample, they declined to state any aspirations. Even goals of making major purchases or setting aside savings proved elusive. Of the twenty percent of retail workers who hoped to build their homes, buy a car or buy furniture, only a third of them made any headway. Those who did were chain retail workers assisted by loans available as part of their benefit packages. More than half of all people were able to save something during at least one of the three years that they were interviewed, but only 30 percent of the sample was able to save all three years.

Despite all these setbacks, hope dies hard. Even in 2008 as the economy weakened, the vast majority of respondents - 93 percent, even including most of the tianguistas expressing resignation continued to nurture one or more aspirations.

\section{Conclusions}

The findings in this study speak to many of the central debates on informal employment, but again, in ways that point to complexity rather than simple dichotomies. We started the analysis with three questions: the degree of convergence or divergence between and within formal and informal retail jobs; the roles of market position, gender, and class in determining worker outcomes; and the impact of neoliberal restructuring on these labor market outcomes.

\section{Convergence and divergence}

While there are some differences between formal and informal workers, in many ways they are overshadowed by inequalities within each of these categories - and convergences across the formalinformal divide. Within our sample, which is qualitatively representative of variation in urban retail employment in the Mexican state of Tlaxcala, the wide pay ranges, differing pay trajectories, and disparate rates of goal attainment within each sector underline these divergences. The gaps between managers and line workers in formal chains, as well as those between public market workers and tianguis or independent vendors in less formal retail, are particularly striking differences. Rank-andfile workers in chains actually earn less on average than any of the informal retail categories, converging with lower-paid informal retail workers.

\section{Determinants of labor outcomes}

Market position - and especially locational capital - is particularly useful in explaining differences between subsectors. The public market, for instance, has multiple market position advantages: a central location, a wide range of merchandise, and week-long opening hours. Public market workers' gains, as earnings in almost all other sectors slumped, are harder to explain, but may be due to consumers switching from chain stores to a cheaper option during the recession.

When it comes to within-sector differences in individual incomes and trajectories, gender and class assume greater prominence. Women report facing labor market discrimination and are more 
likely to exit the labor market altogether to undertake care work. Class, as proxied by access to higher education and social capital, is important in shaping opportunities to move up.

\section{Neoliberal restructuring's impact}

The spread of giant chains is one fruit of neoliberal restructuring. The corporate retailers have created degraded entry-level jobs and taken a bite of the less formal retail market. At the same time, the broader consequences of Mexico's cocktail of neoliberal policies have generated a growing population with no formal employment opportunities, many of whom have joined a survivalist flood into informal retail. The resulting pincer movement on informal retail has in particular squeezed the tianguis and street vendors, sectors with fewer barriers to entry. Disturbingly, the 55 percent of the sample who hoped to start a business were for the most part expressing a hope to enter one of the two more troubled sectors we studied: mom and pop stores and tianguis stands (public market slots are scarce and expensive, and few aspired to become street vendors). Indeed, quite a few of our respondents voiced a clear-eyed analysis of the destructive competition facing small retailers, but simultaneously voiced a hope to open a business, or to add another tianguis stand or sell at another day's mobile marketplace. This pursuit of a questionable strategy speaks both to the value people place on autonomy and flexibility in the workplace and to the lack of economic options facing many in our sample.

In summary, neither homogenization nor polarization adequately characterizes the relation between formal and informal retail work in this Mexican setting. Instead the pattern could perhaps best be described as re-stratification, with wide disparities within both formal and informal work. The reconfiguration of Mexican commerce and the broader reconfiguration of the country's economy have altered the opportunity structure. Workers continue to harbor aspirations and to devise strategies for upward mobility - but on a terrain that, for most, is far from promising.

\section{NOTES}

1. We have borrowed the title of this article from Katz and Darbishire 2002, who use the phrase 'converging divergences' in a different context.

\section{ACKNOWLEDGEMENTS}

We thank Iraida Elena Blanco, Amanda Enrico and Gustavo Madrid for research assistance, and the University of Massachusetts Lowell and UCLA for funding support. 
APPENDIX TABLE A: DESCRIPTIONS OF RETAIL CHAINS

\begin{tabular}{|l|l|}
\hline Chain & Description \\
\hline Aurrera & $\begin{array}{l}\text { Autoservicio (hypermarket/supercenter) selling food, clothing, and a wide } \\
\text { range of other goods, owned by Walmart }\end{array}$ \\
\hline California Vinos y Licores & Liquor stores \\
\hline Comercial Rivera & Medium-sized supermarket \\
\hline Extra & Convenience store \\
\hline Farmacia Guadalajara & Drugstore, selling food as well as standard drugstore items \\
\hline Gigante & $\begin{array}{l}\text { Autoservicio (hypermarket/supercenter) selling food, clothing, and a wide } \\
\text { range of other goods }\end{array}$ \\
\hline ISSSTE & State-owned and -operated medium-sized supermarket \\
\hline Mini Com & Convenience store \\
\hline Oxxo & Convenience store \\
\hline Productos Populares & Medium-sized supermarket \\
\hline Soriana & $\begin{array}{l}\text { Autoservicio (hypermarket/supercenter) selling food, clothing, and a wide } \\
\text { range of other goods }\end{array}$ \\
\hline Super 6 & Convenience store \\
\hline Super Che & Convenience store \\
\hline Super D & Medium-sized supermarket \\
\hline Waldo's & $\begin{array}{l}\text { Variety store, somewhat larger than a convenience store, selling food as } \\
\text { well as other items }\end{array}$ \\
\hline
\end{tabular}

\section{APPENDIX TABLE B: INDICATORS OF LABOR MARKET DISTRESS IN THE STATE OF TLAXCALA, MEXICO, 2006-2008}

\begin{tabular}{|l|l|l|l|}
\hline & \multicolumn{3}{l|}{ Second quarter of: } \\
\hline & 2006 & 2007 & 2008 \\
\hline Unemployment rate & $3.6 \%$ & $4.9 \%$ & $5.5 \%$ \\
\hline Underemployment rate & & 16.2 & 17.3 \\
\hline Informal sector employment rate & & 39.3 & 37.5 \\
\hline \% of paid workers who lack access to social benefits & & 56.3 & 57.5 \\
\hline
\end{tabular}

Source: INEGI (2012).

Note: Indicators other than unemployment rate not available for 2006. 


\section{REFERENCES}

Andersson, F., Holzer, H. and Lane, J. (2005) Moving up or Moving On: Who Advances in the LowWage Labor Market? New York: Russell Sage Foundation.

Avirgan, T., Bivens, J., Gammage, S. (2005) Good Jobs, Bad Jobs, No Jobs: Labor Markets and Informal Work in Egypt, El Salvador, India, Russia, and South Africa. Washington, DC: Economic Policy Institute.

Bargain, O. and Kwenda, P. (2011) 'Earnings structures, informal employment, and selfemployment: New evidence from Brazil, Mexico, and South Africa,' Review of Income and Wealth. 57(S1): S100-S122.

Bernhardt, A., Boushey, L., Dresser, L., and Tilly, C. (2008) The Gloves-Off Economy. Ithaca, NY: Cornell University Press.

Bosch, M. and Maloney, W. (2007) 'Comparative Analysis of labor Market Dynamics Using Markov Processes: An Application to Informality,' World Bank.

Carré, F. and Tilly, C. (2013) 'So far from God, so close to the United States,' and yet...: Unexpected differences in modern retail jobs between Mexico and the United States,' Interventions Économiques/Papers in Political Economy, 47. [Online] Available at http://interventionseconomiques.revues.org/1921, [Accessed: 10 January 2010].

Carré, F., Findlay, P., Tilly, C. and Warhurst. C. (2012) 'Job quality: Scenarios, analysis, and interventions,' in Warhurst, Carré, Findlay, and Tilly, (eds.) Are Bad Jobs Inevitable? London: Palgrave Macmillan.

Castells, M. and Portes, A. (1989) 'World Underneath: The Origins, Dynamics, and Effects of the Informal Economy' in Castells, M., Portes, A. and Benton, L. (eds.) The Informal Economy: Studies in Advanced and Less Developed Countries. Baltimore: Johns Hopkins University Press.

Cobb, C., King, M. and Rodriguez, L. (2009) 'Betwixt and Between: The Spectrum of Formality Revealed in the Labor Market: Experiences of Mexican Migrant Workers in the United States,' Review of Radical Political Economics. 41(3): 365-371.

Cross, J. (1998) Informal Politics: Street Vendors and the State in Mexico City. Stanford: Stanford University Press.

De Soto, H. (1989) The Other Path: The Invisible Revolution in the Third World. New York: Harpercollins.

Fields, G. (2004) Dualism in the labor market: A perspective on the Lewis model after half a century. The Manchester School, 72(6): 724-735.

Funkhouser, E. (1997) 'Demand-side and supply-side explanations for barriers to labor market mobility in developing countries: The case of Guatemala,' Economic Development and Cultural Change. 45(2): 341-66. 
de la Garza Toledo, E. (ed.) (2012a) La Situación del Trabajo en México, 2012: El Trabajo en la Crisis. Mexico City: Plaza y Valdés.

de la Garza Toledo, E. (2012b) 'Notes about the informal sector and its organizations in Mexico,' Unpublished manuscript. México, DF: Universidad Autónoma Metropolitana-Iztapalapa.

Gonçalves, J.R.B., and Madi, M.A.C. (2011) 'Private equity investment and labor: faceless capital and the challenges to trade unions in Brazil,' in Serrano, M. et al. (ed.) Trade unions and the global crisis: Labour's visions, strategies and responses. Geneve: International Labour Office. pp. 97-114.

Gong, X., van Soest, A. and Villagomez, E. (2004) 'Mobility in the Urban Labor Market: A Panel Analysis for México,' Economic Development and Cultural Change. 53(1): 1-36.

Harrison, B. and Bluestone, B. (1988) The Great U-Turn. New York: Basic Books.

Hussmanns, R. (2004) 'Measuring the Informal Economy: From Employment in the Informal Sector to Informal Employment,' Working Paper No. 53, Geneva: International Labour Organization, Bureau of Statistics.

INEGI (Instituto Nacional de Geografia e Informática, Mexico) (2012) Encuesta Nacional de Ocupación y Empleo. [Online] Available at http://www.inegi.org.mx/sistemas/ tabuladosbasicos/, [Accessed: 20 March 2013].

Joubert, C. (2011) 'Pension design with a large informal labor market: Evidence from Chile,' Working Paper, University of North Carolina. [Online] Available at http://www.unc.edu/ -joubertc/submission.pdf, [Accessed: 13 March 2013].

Kalleberg, A. (2012) Good Jobs, Bad Jobs. New York: Russell Sage Foundation.

Katz, H. and Darbishire, O. (2002) Converging Divergences: Worldwide Changes in Employment Systems. Ithaca, NY: Cornell University Press.

Levy, S. (2008) Good Intentions, Bad Outcomes: Social Policy, Informality, and Economic Growth in Mexico. Washington, DC: Brookings Institution Press.

Lichtenstein, N. (2009) The Retail Revolution: How Wal-Mart Created a Brave New World of Business. New York: Metropolitan Books.

Maloney, W.F. (2004) 'Informality revisited,' World Development. 32 (7): 1159-78.

Maloney, W.F. (2003) 'Informal Self-Employment: Poverty Trap or Decent Alternative?,' in Fields, G. and Pfeffermann, G.P. (eds.) Pathways out of Poverty: Private Firms and Economic Mobility in Developing Countries. Boston, Dordrecht, London: Kluwer Academic Publishers.

Negrete Prieto, R. (2012) 'Sector Informal en México visto bajo el esquema conceptual OITGrupo de Delhi,' in de la Garza, E. (ed.) La situación del trabajo en México, 2012: El trabajo en la crisis. Mexico City: Plaza y Váldes. 
Olivo Pérez, M.A. (2012) 'Persistir en el Centro Histórico: El ambulantaje como trabajo no clásico [To persevere in central Mexico City: Street vending as non-classical work],' in de la Garza, E. (ed.) Trabajo No Clásico, Organización y Acción Colectiva. Mexico City: Plaza y Valdés.

Temkin, B. (2009) 'Informal self-employment in developing countries: Entrepreneurship or survivalist strategy? Some implicatios for public policy,' Analyses of Social Issues and Public Policy. 9(1): 135-156.

Tilly, C. (2006) 'Wal-Mart goes south: Sizing up the chain's Mexican success story', in Brunn, S. (ed.) Wal-Mart World. New York: Routledge.

Tilly, C. and Álvarez Galván, J.L. (2006) 'The Mexican Retail Sector in the Age of Globalization: Lousy Jobs, Invisible Unions,' International Labor and Working Class History. 70(1): 1-25.

Tilly, C., Agarwala, R., Mosoetsa, S., Pun, N., Salas, C. Sheikh, H, 2013. Final Report: Informal Worker Organizing as a Strategy for Improving Subcontracted Work in the Textile and Apparel Industries of Brazil, South Africa, India and China. Institute for Research on Labor and Employment, University of California Los Angeles. [Online] Available at http://www.irle.ucla.edu/publications/documents/Informalworkerorganizingintextilesandgarm ents-UCLAReport-9-2013.pdf, [Accessed: 5 January 2014].

Ulyssea, G. and Szerman, D. (2006) Job duration and the informal sector in Brazil. Rio de Janeiro, Brazil: Instituto de Pesquisa Economica Aplicada (IPEA). [Online] Available at http://www.iza.org/conference_files/worldb2007/ulyssea_g3403.pdf, [Accessed: 6 July 2007].

Waldinger, R. and Lapp, M. (1993) 'Back to the Sweatshop or Ahead to the Informal Sector?,' International Journal of Urban and Regional Research. 17(1): 6-29.

\section{BIOGRAPHICAL NOTE}

DIANA DENHAM, editor of the book Teaching Rebellion: Stories from the Grassroots Mobilization in Oaxaca, has masters degrees in Latin American Studies and Urban and Regional Planning from the University of California Los Angeles. She is a doctoral student in Urban Studies at Portland State University, in Portland, Oregon, USA.

[Email: ddenham@pdx.edu]

CHRIS TILLY is a professor of Urban Planning and Sociology and director of the Institute for Research on Labor and Employment at the University of California Los Angeles. He has written extensively on inequality and bad jobs, and ways to improve them, in the U.S. and Mexico. His books include Work under Capitalism, Stories Employers Tell: Race, Skill, and Hiring in America and, more recently, Are Bad Jobs Inevitable?

[Email: ctilly@irle.ucla.edu] 